\title{
Belgeo
}

Revue belge de géographie

\section{«Perspectives »}

\section{Regional organizations and inter-regional relations: competitive models or a bottom-up change of multilateral global governance?}

\section{Mario Telò}

\section{(2) OpenEdition}

Electronic version

URL: http://journals.openedition.org/belgeo/43943

DOI: $10.4000 /$ belgeo.43943

ISSN: 2294-9135

Publisher:

National Committee of Geography of Belgium, Société Royale Belge de Géographie

\section{Electronic reference}

Mario Telò, « «Perspectives »

Regional organizations and inter-regional relations: competitive models or a bottom-up change of multilateral global governance? », Belgeo [Online], 4 | 2020, Online since 09 November 2020, connection on 11 November 2020. URL : http://journals.openedition.org/belgeo/43943 ; DOI : https:// doi.org/10.4000/belgeo.43943

This text was automatically generated on 11 November 2020.

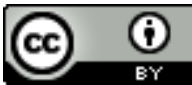

Belgeo est mis à disposition selon les termes de la licence Creative Commons Attribution 4.0 International. 


\title{
«Perspectives »
}

\section{Regional organizations and inter- regional relations: competitive models or a bottom-up change of multilateral global governance?}

\author{
Mario Telò
}

\section{Introduction}

1 The interlinked phenomena of regionalism and interregionalism are both essential aspects of the current debate about the evolution of multilateral cooperation in a context of cultural diversity. How might multilateral cooperation survive in a multipolar world characterized by fragmentation, increasing cultural diversity between and within regions and assertive power politics? Are regional and interregional arrangements part of the global governance problem or perhaps part of the solution in pioneering new forms of multilateral convergence?

2 We start by remembering basic definitions, essential for a research agenda which is, by essence, multidisciplinary. As a prolepsis, for a geographical journal, we define multidisciplinarity as radically different from interdisciplinarity: while the second methodology's ambition is to merge various disciplinary methods and fundamentals, with the aim of building-up a radically new transdisciplinary conceptualization, more modestly multidisciplinarity aims at a limited convergence, among diverse disciplinary research agendas, which remain diverse: a convergence driven by the shared interest for a research object. The object in the case of this journal issue is firstly, "regionalism" as institutionalized cooperation among neighboring states; secondly, 
"interregionalism" as cooperation between regions or entities belonging to different continents.

3 As a preliminary clarification we also remember a trivial empirical distinction. So as many concepts, regionalism has two complementary meanings: either subnational entities (Paasi, Harrison, Jones, 2018) or supranational groupings of neighboring states. They share the gradual loss of centrality of the states within an increasingly multilevel global governance. This essay is focusing on the second meaning, defined by some scholars: macro-regions. Furthermore, while "regionalism" is about relations among neighboring countries belonging to the same continent (Hettne et al., 2001; Hurrell, Fawcett, 1995; Gamble, Paine, 1996; Telò, 2001), "interregionalism" bridges different entities belonging to two or three continents (Rühland, 2005; Söderbaum et al., 2016; Fawcett, Telò, Ponjaert, 2015). Students of comparative politics of geography, history and economics are exploring similarities and differences, achievements and failures of regional cooperation models.

4 Regional organization is a structural feature of global governance since many decades. In the new context of power shifts and enhanced multipolar confrontation, are we witnessing a crisis, an ambiguous evolution, or a dramatic reappraisal of some regional cooperation projects as milestones along more competitive and instrumental paths? And, how might regional cooperation among neighboring states and interregional dialogues or trade arrangements between geographically distant partners contribute to a new post-hegemonic multilateralism?

5 Interregionalism inevitably concerns intercontinental relationships among diverse models and cultures of modernity. Should we regard the contours emerging in the post-hegemonic era as a shift towards an intercultural clash between irreconcilable regions (Huntington, 1996), or as the potential start of a new multidimensional dialogue between diverse partners (Acharya, 2014; Qin, 2018)? New challenges, such as populist nationalism, could seriously undermine both regional and multilateral forms of cooperation. The traditional global order is contested both inside and outside the states. How should multidisciplinary research respond to the need for a new multilateralist research agenda?

\section{Convergences and divergences in national debates about the coming world order}

One major, and highly controversial, line of inquiry sheds light on the evolving global power framework. Beyond the well-publicized divergent viewpoints articulated by Fukuyama (1992) and Huntington (1996) in the aftermath of the Cold War, various theses have been argued about the decline of the global American order (Keohane, 2015; Acharya, 2014; Kupchan, 2012). Haass (2008) has argued that the world is moving towards a fragmented, a-polar world as US power recedes. By contrast, Ikenberry and Deudney (2018) remain convinced that global institutions are robust and resilient enough to cope with these historic challenges.

7 Turning to the EU, the dilemmas of continental Europe are expressions of the conflictual co-existence of two logics. On the one hand, we have the EU's institutional paradigm of reconciliation among erstwhile enemies, designed to put an end to "security dilemmas." On the other we are witnessing the recent neo-nationalist trend. 
On a de facto basis, these debates converge drawing two alternative scenarios for the future. The world is headed either toward hard power politics, based on a multipolar or bipolar confrontation, or toward a heterogeneous system that features new forms of multilateral cooperation. Logically, only the latter paradigm is potentially respectful of the "constraining diversities" that characterize our current situation. And only the latter offers other global actors - such as the EU, India, Japan, Indonesia, Australia, Canada, the African Union, ASEAN, and MERCOSUR - a potentially relevant role in regional, interregional, and global governance. of course regional entities should be comparatively verified as their main trends of development: are they closed fortresses or are they open venue for interregional multipurpose partnerships?

\section{Conceptualizing and comparing interregionalist partnerships as a test for intercultural dialogue}

9 Interregional relations are understudied even though they are crucial in modifying the debate about the global order and the development of regional entities. The first conceptual debate about the role of interregional relations started in the 1990s, under the auspices of the "Rio process" between the EU and Latin America. The ASEM (AsiaEurope meeting), which celebrated its 12th summit in Ulaanbaatar on October 18, 2018, was launched in Bangkok in 1996. Many scholars also would include the former ACP, started in 1973 via the Yaoundé Convention, in the same conceptual framework because the EU's partners in that organization were located in other parts of the world: namely, Africa, Oceania, and Caribbean. Multiple conceptual controversies emerged in the academic world around the turn of the new century. At that time, it became clear that in the 1990s, the US had developed its own interregional relationships, based on Fred Bergsten's theory of “emerging markets" (Bergsten, 1994). These included ties with Latin America (the FTAA, formed in 1994, which failed in 2005); with Asia and the Pacific (APEC, formed in 1994); and with Europe (the new Transatlantic Agenda of the 1990s). For its part, the EU - in the context of its new ambitions as global actor negotiated almost a dozen parallel "Strategic partnerships" (with China in 2003, India in 2004, Brazil in 2007, and many more later on) and several trade arrangements with individual countries or with a group of countries. These initiatives raised some important theoretical issues: e.g., whether in a de facto sense such Strategic partnerships (as well as some EPA -"European partnership agreement" - with single African countries) were opposed to region-to-region partnerships, and/or to bloc-tobloc relations (Santander, 2016).

10 However, the majority of the epistemic community shares a flexible and comprehensive concept of interregional relations which could be summarized as follows: "multidimensional relations between one region, on the one hand, and a region or a large state on the other, belonging to two or three different continents." By this definition, the EU-China partnership, BRI, TTIP, CETA and TPP, all would count as interregional relations. To characterize this second type of interregional relations with greater precision, the concept of "hybrid interregionalism" has been proposed and now is shared by several scholars (Rühland, 2015; Soederbaum et al., 2016; Fawcett et al., 2015).

11 The main point to be brought out here is that a regional organization may play a decisive role as at least one of the partners within a scheme of interregional 
cooperation. In this respect, we are witnessing a multiplication of interregional relations, such as those launched by ASEAN, MERCOSUR, and the African Union.

By this encompassing definition it is possible to assert that, like regionalism, interregionalism is a structural feature of an increasingly multilayered system of global governance in which the global multilateral set is no longer the sole framework for institutionalized cooperation. As a significant development of the UN Charter of 1945, the balance between the regional/ interregional level of governance and the global level is shifting in favor of the former. Both Boutros Boutros-Ghali and Kofi Annan recognized, on behalf of the UN, the increasing relevance of the sub-global (notably the regional) dimension of governance in helping to prevent or manage conflicts and establish economic cooperation. The fact that two UN Secretary-Generals saw the value of regionalism itself has had an impact, helping to sustain regional organizations and foster regional identities.

But there is another, less positive take on this trend. Globalist economic liberals, reflecting on the place of such ties within the system of global governance (Bhagwati, 1992), likely might see both regionalism and interregionalism as a symptom of the fragmentation of the global framework. Yet undoubtedly, regional cooperation eventually encourages interregional ties, trade partnerships, and sometimes even cultural dialogues. Thus, the normative criticisms that leveled by Bhagwati against regional and interregional trade arrangements are outdated, but his remarks suggest a different and stimulating observation. Regional and interregional arrangements may be driven by factors other than trade interests. As scholars of the new regionalism assert, the explosion of these phenomena can be analyzed comparatively as a trend towards a "world of regions" (Katzenstein, 2005), a longue durée and structural process of multilayered transformation of global governance (Fawcett, Hurrell, 1995; Hettne et al., 2001; Hettne, 2008; Telò, 2001, 2016; Risse, Boerzel, 2016; Gamble, Paine 1996). Normative condemnations in the name of economic neo-liberalism seem inappropriate for a multidisciplinary research agenda. Regions develop their own identities and interregional relations, including by trade arrangements. Such regional and interregional relationships are no longer a matter of mere rational choice alone; instead, they reflect political decisions, as well as shared values, standards, perceptions, and ways of life.

14 All in all, the development of multipurpose regionalism and interregionalism also can be seen as the only way possible to revive and reform global multilateralism, by enhancing not only its efficiency but also its legitimacy, because regional governance often plays the role of a bottom-up support of global governance. In this way, the new regionalism goes beyond the limits of the famous debate between Bhagwati and Summers in the early 90s, which was limited to trade dimensions (see Morin et al., 2015; De Block, Lebullinger, 2018).

In terms of its theoretical implications, interregionalism is a form of multidimensional cooperation that may include cultural identities and feelings of common belonging, which together may help to ward off, or at least to limit, anarchy, nationalism, competition, ethnocentrism, protectionism, and fragmentation.

16 Interregionalism belongs to the realm of new complex institutional sets and frameworks of complex interdependence, operating within a highly contested scheme of global governance. In these ways, it transcends the old realist thought, even if the latter appears to have made a comeback, being revived by the nationalist challenge 
posed by extreme right nationalism ("populist realism" according to Qin 2018) in many countries.

\section{Diachronic dimensions of EU's interregionalism from the 1990s to the present}

17 A second relevant debate within the international epistemic community has concerned the evolution of interregional relations in the aftermath of the Cold War and its impact on regional cooperation. During the first decade, which Andrew Gamble (2014) has termed the era of "liberal peace," the Clinton/ Bergsten approach to regional cooperation was essentially economic and instrumental, focusing on free trade areas in the three directions mentioned above; that approach was expected to revive a hegemonic style: hegemonic in the sense meant by Keohane (1984). The Clinton/ Bergsten approach would dispute the hegemonic decline of the United States, which began in 1971, with the end of the Gold standard based on the US dollar. Nevertheless, that approach was consistent with the so-called IMF "Washington Consensus" (1989) and Western neoliberal culture. In the three cases - APEC, FTAA, and New Transatlantic Agenda - it sparked bitter conflicts with deeper regional organizations such as MERCOSUR in South America, ASEAN in the Asia-Pacific zone, and the EU in the transatlantic area. These three examples of regional cooperation encompassed political and cultural implications as well, which were incompatible with the USA's neohegemonic and rational-choice approach to international relations.

The effort by George W. Bush to subordinate interregional agendas to security concerns after 2001 - the era of "liberal war," according to Gamble (2014) - sharpened the resistance of the various partners to US-led interregional projects. As a result, the interregional projects of the US largely went nowhere. This debacle confirmed the failure of earlier attempts by Clinton and by G.H.W. Bush to revive the declining hegemonic, US-led multilateralism by relying on interregional arrangements, whether focused on free trade or security. Such interregional setbacks were paralleled by the shortcomings of the WTO-DDR from Seattle (2000) to Cancun (2003) and the failure of the "liberal wars" in Iraq and Afghanistan. During the same period, the Southeast Asian economic crisis provoked a regionalist reaction against the IMF and the Washington Consensus while fostered the deepening of the ASEAN integration process. The latter began expanding into monetary, political, and cultural fields. For example, the "Chang Mai Initiative" for a regional fund that began in 2000 was supported by ASEAN, China, Japan, and South Korea as a critical step towards IMF rules.

Academics at this time, at least in the field of international relations, still focused on comparing the competing US-led and EU-led interregional endeavors. Two main differences between the approaches of the EU and USA, as underlined by prominent scholars like Hettne (2007), stood out. First, while the EU's interregional relations were multipurpose (economic, cultural, environmental, social, and political), US-led arrangements were either only free trade-oriented or security-oriented with G.W.Bush (e.g., in the realm of anti-terrorism). EU interregionalism included three baskets: socio/ cultural and environmental cooperation, economic cooperation, and political dialogue. That approach could be considered an example of the politicization of interregional partnerships in defense of multilateralism. The condemnation of the United States' 
preventive war in Iraqi by the EU-CELAC interregional meeting of 2003 in Guadalajara suggests what such politicization might accomplish.

A second difference in this regard is that interregional relations started by the EU typically supported multidimensional regional integration abroad, whereas US-led efforts were at cross-purposes with deeper regional integration. The EU approach made it possible not only to engage in various form of "diffusion" or regionalism abroad (Risse, 2016), while not always avoiding excessive emulation and mimesis and the arrogant normative emphasis on the "EU model" and "normative power" (Manners, 2002).

\section{The emergence of competing regionalisms and interregionalisms: convergences, failures, and power relations}

Since 2010, the international scholarly debate on global governance has changed dramatically due to the economic and financial crisis, the rapid emergence of China, and the rise of the BRICS. An issue raised years ago by Hettne (2007) has gained saliency in the present political context: do interregional relations facilitate the cohesion of regional partners or are they more likely to divide and disintegrate the partner organization as a bloc? Bloc-to-bloc negotiations (e.g., EU/ASEAN, EU/AU and EU/ MERCOSUR) are an identity marker in which each partner has a direct mirror interest in mutually supporting the other's current and future internal integration. The EU's policy on cooperation with ASEAN for disaster relief and security issues provides a positive example (cf. GEM research project, notably that by Tercovich, 2019). In what follows, we will try to assess whether interregional relations spur integration or division around the world. As will become apparent, the role and nature of the leading partner - whether that be the US, Russia, China, and the EU - is often decisive in determining the answer.

Under the Trump administration, the US has been abandoning the enhanced global role sought by Presidents Clinton and Obama through mega-interregional trade arrangements. The turning point was Trump's decision to delegitimize the global multilateral network (WTO and its panels) and to dismantle the Obama attempt to revive US interregional hegemony though the TPP and TTIP. The only alternative to those efforts that Trump accepts - aside from national protectionism and trade wars is to undertake hierarchical revisions of previous regional and interregional arrangements that allegedly will favor US interests, including in symbolic terms. For example. NAFTA was simply rebaptized as USCMA in order to put the US first even in the acronym while deleting the acronym FTA. We may define this sort of regionalism as a form of hierarchical transactionalism combining two bilateral relationships, the opposite of true multilateral regionalism. In the event that Trump should propose the same for US relations with Japan, the UK, China, and the EU, heightened tensions may occur. The partner matters, as well as its politics and/or vision of the best possible combination of bilateralism, interregionalism, and multilateralism.

In this context it is notable that both the US under Trump and Russia under Putin explicitly seek the dismemberment of the EU. Putin is funding extremist anti-EU nationalist far right wing parties in order to weaken and divide the Union. For his part, 
Trump famously proposed Brexit to EU member states as a model and described even NATO as "obsolete", throwing the organization into a crisis that may presage its decline. These policies imperil transatlantic interregionalism, much as the US withdrawal from the Trans-Pacific Partnership agreement vitiated prospects for enhanced transpacific cooperation including the US.

Particularly relevant for the future of pan-European, East/West interregional relations is the way that Putin's hard policies toward Georgia and Ukraine have transformed the potentially complementary EU and Eurasian Economic Union constructs (EAEU) into strategically competing projects. Under this new scenario, defections from the Eurasian Community in favor of pro-EU arrangements may be either punished by military invasion, as has occurred in eastern Ukraine, Abkhazia, and South Ossetia, or subjected to blackmail by the withholding of energy supplies, as happened to Armenia. To be sure, Russia's conduct was motivated by what it perceived to be the threat in its own backyard posed by NATO's eastward expansion after 1991. Still, that conduct, which led to the EU's unanimous sanctions against Russia, indicate the dangerous collapse of the peaceful Pan-European interregional architecture established after 1990-91, as embodied in the Council of Europe, OSCE, Russia-NATO Council, and strategic partnership between the EU and Russia.

25 Authoritarian regimes like Putin's Russia sometimes work to foster regional and interregional cooperation. Typically, they do so for geopolitical defensive advantages, or when they think that such moves will promote autocracy in their neighborhood and/or a "hard" version of multipolarity. However, as far as Putin's vision and practice of regional cooperation is concerned, the absence of democracy, bottom-up drivers, and civil society actors all are factors limiting regional cooperation and shaping it an unprecedented way. Furthermore, one must consider the internal mechanisms enabling or constraining relations between autocrats leading member states. In this context, security is the main engine of regime-building. Because of its internal rules and procedures, this top-down, hierarchical version of regionalism cannot be multilateral and scholars do underline the substantial diversity from new regional democratic regionalism.

Notwithstanding these limits, it is very interesting that today large states, including Russia, want to coordinate policies at the regional level, thus moving - to some extent beyond the old imperial concept of spheres of influence that prevailed in the 19th century. Regional and interregional relations may matter by shaping the future of regional entities characterized by alternative values, features and identities in competing directions. So, on the one hand, the EU potentially could influence parts of the Eurasian community, such as Moldova, Belarus, Ukraine, the Caucasus. On the other hand, China's regional policy in central Asia, notably the Shanghai Cooperation Organization (with its "Chinese characteristics"), may be critical as the future evolution of the EAEU is concerned.

As far as the EU is concerned, the quasi-continental enlargement policy, reflected in that body's growth from 12 to 27 member states plus 5 applicants, is widely regarded as a success-story. By contrast, the EU's attempt to establish interregional relationships with the "arc of crisis" countries, from Ukraine and Belarus to Libya and the Arab nations - exemplified in the "Barcelona process" and the European neighborhood policy - largely can be judged a quasi-failure, at least so far, and a challenge awaiting future resolution. Cultural cleavages do affect this failure, not only on the southern 
flank (cf. the poor record of the EU's multiple attempts at a cultural dialogue with Islam), but also on the eastern flank, as shown by the oscillating relationship with Moldova, the Caucasus states, and Belarus, and the deadlock in educational and cultural cooperation with Russia. The latter shows up in the frozen bilateral strategic partnerships between the EU and Russia as well in both the Council of Europe (regarding the crucial dimension of human rights protection) and OSCE (regarding the monitoring of democratic transitions).

Comparative studies offer evidence of the authoritarian evolution of top-down regional cooperation organizations also elsewhere, notably in the cases of the Gulf Cooperation Council. The latter has been described as an instrument of Saudi Arabia's hierarchical rule, exemplified by its campaign against Qatar, which has been accused of complicity with Iran. Another case of such authoritarian evolution is ALBA, a political instrument of the declining Venezuela influencing poorer countries. Authoritarian regionalism is an alternative model of regional cooperation, distinct from soft/relational and deep/ institutionalized regionalism, which are both based on bottom-up legitimacy and multilateral rules. The latter models would include the multipurpose entities of EU, ASEAN, MERCOSUR, and SADC, no matter what the main driving factors (security, trade, or institutions) behind them may have been.

China's interregional relations in the Xi era (and the "post-peaceful rising period") that was openly proclaimed by the 19th CCP Congress are instructive. The Belt and Road Initiative (BRI) exemplifies a unilateral interregional global project of staggering magnitude. Are China's interregional policies in Asia, Africa, Europe, and Latin America evolving towards a multilateral or hierarchical pattern, and are they uniting or dividing the various regional/continental partners? In regard to China's relations to Europe, we are witnessing a paradox. For many decades the consensus among international observers was that China strongly supported the unity of the EU as well as further integration, with the purpose of counterbalancing the power of the US and the USSR/Russia. However, it has become apparent that China is currently making a twofold European policy, notably by the 17+1 arrangement with central and eastern European countries. The attempt to reach out to Europe, manifested most recently in Xi Jinping's 2018 and 2019 visits to Brussels, has deep roots in Chinese history, extending not only back to Deng Xiaoping but even to Mao Zedong's vision of a multipolar world and a politically united Europe's balancing role both in trans-Atlantic and PanEuropean relations. Moreover, Xi's support for the EU runs parallel to China's controversial political and financial support for the African Union. China has offered to build the AU's headquarters in Addis Ababa and promised to upgrade Chinese investments within the AU. However, as part of its BRI, China is now institutionalizing its relationships with 17 European states. In a de facto sense, China is thus dividing the $\mathrm{EU}$, much to the dismay of those in charge of the European Union's institutions.

The shift in China's European policy is part of a broader set sea change. In the Xi Jinping era, China has increased its assertiveness as a global actor. It is in the process of developing its own practices, characteristics, and ideas of global multilateralism and regionalism, both in its own neighborhood and in interregional relations with Africa and Europe (via the BRI) as well as Latin America. The China-Africa partnership has developed enormously since 2010, and these interregional economic ties are supported by political objectives. Most analyses of China's offensive diplomacy in Africa have focused on Beijing's thirst for economic benefits in regard to energy and raw materials. 
That is why its behavior often is dubbed "energy diplomacy" or "economic diplomacy", implying that China, like Japan in the 1980s, seeks to become a "geo-economic power". But if one looks at the history of the PRC's foreign policy, one realizes that Beijing has seldom pursued its diplomacy based on purely economic considerations. Chinese interregionalism in Africa should be viewed through a political lens, in light of geostrategic calculations, political and security ties with African countries, peacekeeping and anti-piracy efforts, and support for African regionalism. China's diplomatic expansion in Africa, while partially driven by its need for economic growth, cannot be fully understood without taking into consideration the strategic impulses accompanying its accelerating emergence as a global power. Africa's interregional partnership is one of China's diplomatic "new frontiers", as exemplified by new Chinese leader Xi Jinping's maiden foreign trip to Africa in 2013 and in following years. That is why the huge FDI plan for Africa has been interpreted by some international commentators as an excellent opportunity, but also as posing a risk of division and geopolitical domination.

In short, recent events are obliging neutral observers to address the question of the nature of China's interregionalism by typing in a question mark. The deepening of relations between China, on the one hand, and 17 E.U. and non-EU Eastern European states, and the bilateral arrangements made with Portugal and Italy in 2019, on the other, is weakening the institutional role of the EU central institutions as the main coordinator of Europe's external cooperation, trade, and partnerships. They are also de facto strengthening Euro-skeptical governments such as those of Orbán in Hungary, Kaczynski in Poland, and Conte/Salvini in Italy (2018-2019). In the context of the economic decline of southern EU member states after the financial crisis 2009-17, it is also worthy of mention that China's decision to prioritize individual relations with single EU countries, notably with the weakest like Greece, provokes worries regarding its political designs.

It would be blind to deny that the Belt and Road Initiative presents an interregional opportunity of historic importance for all, including Africa, Asia, Latin America, and the EU. Presented by Xi Jinping as the "project of the century," it is one of the pillars of the "Third Chinese Revolution" (after those spearheaded by Mao and Deng: cf. Economy, 2018), beyond the period of the so-called "peaceful rise." It will be a crucial test for China's interregionalism and multilateralism.

The USA opposes the BRI as a major rival to its own global influence and a risky bargain for weak states. Does the launch of the BRI presage a neo-hegemonic shift? If its implementation openly serves the geopolitical interests of a single great power, thereby promoting a one-sided understanding of globalization, it will provoke resistance, criticism, and containment. Comparisons with the American Marshall Plan of 1947-57 may be useful. The Marshall Plan's inspiration was innovative and enlightened Keynesianism. John Maynard Keynes believed that the shortcomings of the Versailles conference in 1919 stemmed from (among other things) a flawed understanding of international economic relations that he had tried (and failed) to correct. He ended up "winning" at the Bretton Woods conference in 1944, converging with the Roosevelt brain trust on the idea that the new postwar economic order must be based on multilateral agreements. However, largely due to Stalin's opposition, the Marshall Plan by 1947 had become de facto also an instrument of the Cold War and the containment policy developed - under George Kennan advice-. In combination, the 
Marshall Plan and the policy of containment became the twin linchpins of US hegemony (Keohane, 1984, 2004; Ruggie, 1993; Patrick, 2009). That hegemony involved providing international public goods, promoting the European Organization for Economic Cooperation as a new multilateral institution, and applying the logic of power politics to the bipolar confrontation between the US and the USSR. Especially in the wake of Stalin's 1948 refusal to allow the participation of Czechoslovakia and Yugoslavia in the Marshall Plan, it became effectively impossible for US aid recipients to reject demands to join NATO.

We are not (not yet) in an era of bipolar confrontation, and there is no "Thucydides trap" between China and the West lurking around the corner (Allison, 2017). But what still remains inspiring in this troubled time for a true hegemonic project is that the multilateral approach taken by the US after World War II managed to survive the Cold War, thanks to both its links to global economic growth and the attractiveness of the "American way of life" as a form of soft power. Assuming that China is not seeking to use the BRI to pursue international hegemony, it will need to expand the nature of its international public goods provision, offer its autonomous partners opportunities for economic growth, enhance its soft power dimension, and foster shared interregional leadership within a revived multilateral network in order to limit the impact of negative feedback and foil policies of containment by the US and other actors. The quality of its partnership with the EU and possible convergences both at the global and interregional levels are crucial. These are the key variables that may influence this potentially virtuous interregional scenario. Here, a triangular partnership among China, the EU, and Africa would be a relevant test.

The most daunting challenge facing a pluralist, multiple-style multilateralism is how to combine trade with other interregional issues, thereby linking external relations to internal policies. Traditionally, trade was a matter of technocratic, de-politicized global or interregional relations. However, this is changing dramatically, as a comparison of Chinese and EU approaches to foreign policy makes clear. Whereas the accent in China is on "multilateralism with Chinese characteristics" (19 ${ }^{\text {th }}$ CCP Congress, 2017), the EU strives to embody its own values in the making of foreign policy. In other words, the EU's cultural traditions extend even to its trade policy. Of course, future posthegemonic multilateralism will have to be based on pluralist convergence among very diverse approaches, political styles, background cultures, and divergent ways of making policy. Ignoring this principle slowed progress in expanding multilateral trading relations. No country wants to buy another's values in unilateral way, in addition to its commercial products. When interregional dialogue misses a two-way exchange, a negative feed-back is to be expected by the junior partner.

In the aftermath of the Treaty of Lisbon, which went into effect in 2009, the EU attempted to create a comprehensive approach to foreign policy and a kind of single pillar of external relations. Legally framed by the Treaty of the EU (TEU) and the Treaty on the Functioning of the EU (TFEU), that approach obliges EU policymakers to promote human rights and sustainable development, among other general aims. EU Trade Commissioner Cecelia Malmstrom's 2015 paper, entitled "Trade for All," emphasized that "economic growth goes hand in hand with social justice, respect for human rights, high labor and environmental standards, and health and safety protection" (2015, p. 10). Finally, the "EU Global strategy" approved in 2016, following a proposal by the High Representative for Foreign Policy Federica Mogherini, commits 
the EU to "harmonizing trade arrangements not only with development goals but also with sustainable development, environmental protection, health, safety, human rights protection and foreign policy strategy".

This approach is counterbalanced and framed by a strong emphasis on regional and interregional partnerships, in which the EU does not have to provide lessons to the partners. The previous Eurocentric and arrogant perspective of "normative power Europe" (Manners, 2002) looks as definitely over, and not only because it provoked negative feedback on every continent, as Acharya (2014) and other scholars have underlined.

What can be said about the impact of this controversial evolution? Are these ambitious objectives realistic? Between 2010 and 2018, the EU negotiated and signed a series of relevant "second generation trade arrangements" with interregional partners like South Korea, Vietnam, Japan, Canada, MERCOSUR (De Block, Lebullinger, 2018). Similar arrangements are under negotiation with Australia, ASEAN and New Zealand. These complex and multipurpose interregional partnerships are politically relevant, notably in the Asia-Pacific region, because they address the huge vacuum created by the inward-looking and protectionist policy of Donald Trump. Although arrangements about foreign investments were located in the sphere of EU competence by the Lisbon Treaty, this competence was fine-tuned by the European Court of Justice in 2019. For that reason, the difficulties involving several ongoing negotiations, including the Bilateral Investment Treaty with China, are understandable. Is China likely to agree to seek some relevant improvements in respect for the rule of law in general and labor law in particular? Transparency and fairness in business are the conditions for attracting foreign investments, increasing trade, building financial and economic partnerships. Consequently, they are among the goals of President Xi Jinping, as announced at the party congress of 2018. However, many problems exist that touch on the domestic impact of multilateral standards. For example, divergences in the notions of the rule of law and human rights have not yet been successfully addressed by the EUChina "human rights dialogue" (Ding et al., 2017). In addition, the question of labor rights is affecting the BIT agenda.

Could the EU simply forget about complying with its demanding treaty and strategy provisions? Doing so would not be easy, first because of the Lisbon Treaty provision that has altered the process through which trade policy acquires legitimacy. The treaty calls for enhanced democratic accountability and transparency by bestowing an oversight role on the EU parliament. Moreover, that body has the final word on ratification and carries on a constant dialogue with very persistent NGOs. The Lisbon Treaty thus has changed the parameters and now requires closer cooperation among the Commission, the Council, and the Parliament. In effect, it integrates the Parliament into the established decision-making system. Furthermore, after the declaration by the Commission that some trade and investment arrangements such as CETA are "mixed treaties" that require the signatures of and ratification by both the EU and the member states, some of the latter have accepted and even supported the bottom-up politicization of EU trade policy. They have chosen to submit treaties to national and even sub-national (in the case of Belgium) majority decision-making. Legitimacy is very relevant a true priority. However, according to many observers, that complex internal ratification procedure may undermine the credibility of the EU in international and interregional negotiations. 
40 Is this more rigorous process on the part of the EU a sign of unilateral arrogance that will make beneficial trade deals harder to negotiate and less effective once they are? Or should the new system be considered, if not an example to be followed by partners, a constructive factor, fostering higher standards in commercial arrangements, as it did in several instances, notably in the cases of Canada, Mexico, MERCOSUR, Japan, and Asia-Pacific? It is too early to answer this crucial comparative research question.

\section{Conclusions}

41 Both regional cooperation and interregional multipurpose partnerships are extremely significant in many fields of global governance, including trade, economics, environment and politics. However, in a context of increasing competition with alternative authoritarian models, the bottom-up, democratic and multilateral type cannot progress without a substantial political upgrading, and without seriously while gradually addressing the respective background cultures and their profound differences. To cite just one case in which the background culture has an enormous impact on politics, we spent a part of this essay in considering the case of EU relations with China. There, the legacy of the Confucian background is not merely rhetorical; it is one of the country's main strong points. Despite their internal debates, eminent Chinese scholars do agree on this, including Qin (2008), Yan (2011) and Zhao (2016), all of whom have argued eloquently for the continuing relevance of Confucianism in China (see for example the April 2018 conference at CFAU University, Beijing) for the current approaches to international and interregional relations. Turning to the European Union, we would encounter broad agreement that, at least on the continent and excluding the UK, the Enlightenment tradition and the value of peaceful reconciliation between previous enemies still matter a great deal in supporting the integration process and open interregional relations. Christian, liberal and social democratic thought constitute some of the building blocks of the shared pluralist European background culture that supports peaceful, cooperative governance beyond the state and between the states and regions (Telò, 2018).

42 The international multidisciplinary epistemic community should look for new, creative, pluralist theories of global governance beyond the state, and identify the sources of thought and action that might implement such governance in the polymorphic international life of the 21st century. To what extent and under which conditions is the European "background knowledge" compatible with intercultural dialogue and "relational multilateralism"? Beyond traditional universalism we will need "differentiated universalism" as a bottom-up way to overcome the risk of relativism while respecting the geographic territorial dimension. These should be topics for multidisciplinary research programs including political science, economics, law, philosophy, history and geography. In any case, it is a matter of fact that the territorial and transnational dimension of the world polity plays a crucial role in sustaining interregionalism in several ways, notably by making it more efficient, legitimate, and able to frame balanced dialogue among cultures. Memory also matters: thinkers such as Habermas (2001), and Bobbio (1999), among others, have made it clear that this cathartic feature of European political culture marked a radical turning point against centuries of tragic conflicts and wars provoked by extreme nationalism during the first decades of the 20th century, the most violent period in European history. In 
the very moment at which movements have arisen that revive the pre-1945 nationalist specter, it is important to underline this feature of the European political background culture, one that is the very soul of European reconciliation and is open to intercultural dialogue. Similar reconciliation processes are ongoing in South America and Southeast Asia, while they are in deadlock or in stalemate in South Asia (India-Pakistan) Middle East, and East Asia (China-Japan).

The alternative to dialogue and reconciliation between geographical neighbors or distant partners would be the nightmare of a cultural and civilizational regression towards extreme nationalism, perhaps a kind of Huntingtonian clash between irreconcilable regions (Huntington 1996). Peaceful interregional transnationalism based on internal reconciliation is not the identity marker emerging from European societies 75 years after 1945: it has lasted as a critical factor in promoting peace though socio-economic integration and governance beyond the state. As a consequence of the financial crisis that began in 2007-08, nationalism has returned in the form of populism, protectionism, and intolerance. It poses a threat not only to domestic democracy but also to interregional and multilateral cooperation. What is new is that the populist rhetoric deploys democracy as a rhetorical weapon against three targets: openness, European integration, and interregional relations with other continents, notably with Africa, South America, East Asia and China.

The way of interregional dialogue even if controversial is realistic enough. Partner cultures exist in each continent as potential ideational constructive factors. We already mentioned the potentials of the Confucian culture. In other continents, for example, Pan-Africanists such as Henry Sylvester Williams, Kwame Nkrumah, Julius Nyerere, and Kofi Annan (Yusuf, 2014) and Pan-Americanists like Simón Bolívar added very much concerning the synthesis between patriotism, freedom, regional and interregional cooperation. This innovative way forward might lead to several confidence-building processes, trust-building dialogues, while gradually allowing governance beyond the state to be transformed from an instrumental into a binding process supporting common struggles for common global goods. This gradual revision of the traditional Westphalian paradigm towards a multilayered, post-hegemonic multilateral governance is very controversial, but, to some extent, already underway.

\section{BIBLIOGRAPHY}

ACHARYA A. (2009), Whose Ideas Matter? Agency and power in Asian regionalism, Ithaca, NY \& London, Cornell University Press.

ACHARYA A. (2014), The End of American World Order, London, Polity.

ACHARYA A. (2017), Global Governance in a Multiplex World, Fiesole, Italy, IUE papers.

ALLISON G. (2017), Destined for War, Melbourne, Scribe.

BERGSTEN F. (1994), “APEC and the World Economy”, in GARNAUT R., DRYSDALE P. (eds.), Asia

Pacific Regionalism, Sydney, Harper, pp. 218-225. 
BHAGWATI J. (1992), “Regionalism versus Multilateralism”, The World Economy, 15, 5, pp. 535-555. BOBBIO N. (1999), "Etat et Democratie Internationale”, in TELÒ M. (ed.), Démocratie et relations internationales, Bruxelles, Complexe, pp. 143-158.

DE BLOCK C., LEBULLINGER J. (2018), Génération TAFTA/CETA: Les nouveaux partenariats de la mondialisation, Montréal, Université de Montréal.

DING C., ZHANG X. \& TELÒ M. (eds.) (2018), Deepening EU-China Partnership. Bridging ideational and institutional difference, Abingdon, UK, Routledge.

ECONOMY E. (2018), The Third Revolution; Xi Jinping and the new Chinese state, Oxford, UK, Oxford University Press.

FAWCETT L., HURRELL A. (1995), Regionalism and World Politics, Cambridge, UK, Cambridge University Press.

FAWCETT L., TELÒ M. \& PONJAERT F. (eds.) (2015), Interregionalism and the EU, London, Routledge.

FITRIANI E. (2014), South East Asians and ASEM, Singapore, ISEAS.

FUKUYAMA F. (1992), The End of History and the Last Man, New York, Free Press.

GAMBLE A. (2014), "Regional Blocs, World Order, and New Medievalism”, in TELÒ M. (ed.), EU and New Regionalism, Burlington, VT, Ashgate, pp. 21-36.

GAMBLE A., PAYNE A. (eds.) (1996), Regionalism and World Order, London, Red Globe.

HAASS R. (2008), “The Age of Non-polarity: What will follow the US dominance”, Foreign Affairs, 87, 3, http://www.foreignaffairs.com/articles/world/2017-02-13/internet-whole-and-free.

HABERMAS J. (2002), “A Constitution for Europe?”, New Left Review, 11, pp. 1-15.

HELD D. (1995), Democracy and Global Order, Cambridge, UK, Polity.

HETTNE B. (2003), “The New Regionalism Revisited”, in SÖDERBAUM F., SHAW T. (eds.), Theories of New Regionalism: A Palgrave Reader, Basingstoke, UK, Palgrave Macmillan, pp. 22-24.

HETTNE B. (2007), “Interregionalism and World Order: The diverging EU and US models", in TELÒ M. (ed.), EU and New Regionalism, Burlington, VT, Ashgate, pp. 75-105.

HETTNE B. (2008), “Regionalism and World Order”, in FARRELL M., HETTNE B. \& VAN LANGENHORE L. (eds.), Global Politics of Regionalism, London, Pluto Press, pp. 269-286.

HETTNE B., INOTAI A. \& SUNKEL O. (eds.) (2001), Comparative Regionalism, London, Palgrave.

HUNTINGTON S. (1996), The Clash of Civilizations and the Remaking of World Order, New York, Simon \& Schuster.

IKENBERRY J., DEUDNEY D. (2018), “Liberal World: The resilient order”, Foreign Affairs, 94, 4, pp. 1-15.

JANCIC D. (2019), The Role of the EP in EU-China Relations, Collège of Bruges Conference, Brussels.

KATZENSTEIN P. (2005), A World of Regions, Ithaca, NY, Cornell University Press.

KEOHANE R. (1984/2004), After Hegemony, Princeton, NJ, Princeton University Press.

KEOHANE R. (2015), “Contested Multilateralism”, in MORIN et al. (eds.), The Politics of Transatlantic Trade Negotiations, Burlington, VT, Routledge, pp. 17-27.

KEOHANE R., NYE J. (eds.), 2014), Transnational Relations and World Politics, Cambridge, MA, Harvard University Press. 
KUPCHAN C. (2012), No One's World, Oxford, UK, Oxford University Press.

MALMSTRÖM C. (2015), “Trade for All”, Brussels Report of EU Commission, pp. 10-20.

MANNERS I. (2002), “Normative Power Europe: A contradiction in terms?”, Journal of Common Market Studies, 40, 2, pp. 235-258.

MARRAMAO G. (2017), Filosofie dei Mondi Globali, Torino, Italy, Bollati.

MEYER T., DE SALES MARQUES J. (eds.), 2018), Multiple Modernities and Good Governance, London \& New York, Routledge.

MEYER T., DE SALES MARQUES J. \& TELÒ M. (eds.) (2020), Cultures, Nationalism and Populism, London \& New York, Routledge.

MORIN J., NOVOTNA T., PONJAERT F. \& TELÒ M. (eds.) (2015), The Politics of Transatlantic Trade Negotiations, Burlington, VT, Routledge.

NYE J. (1968), International Regionalism: Readings, Boston, MA, Little, Brown.

PAASI A., HARRISON J. \& JONES M. (eds.) (2018), Handbook on the Geographies of Regions and Territories, London, Elgar.

PATRICK S. (2009), The Best Laid Plans, Lanham, MD, Rowman \& Littlefield.

QIN Y. (2018), A Relational Theory of World Politics, Cambridge, UK, Cambridge University Press.

RISSE T., BÖRZEL T. (eds.) (2016), The Oxford Handbook of Comparative Regionalism, Oxford, UK, Oxford University Press.

RÜLAND J. (2006), “Interregionalism: An unfinished agenda”, in HÄNGGI H., ROLOFF R. \& RÜLAND J. (eds.), Interregionalism and International Relations, London, Routledge, pp. 295-313.

RÜLAND J. (2015), “The Unintended Consequences of Interregional Democracy Promotion: Normative and conceptual misunderstanding in EU-ASEAN relations", in TELÒ M., FAWCETT L. (eds.), Interregionalism and the European Union, Abington, UK, Routledge, pp. 267-283.

RUGGIE J. (ed.) (1993), Multilateralism Matters, New York, Columbia University Press.

SANTANDER S. (2016), Concurrences régionales dans un monde multipolaire émergent, Bruxelles, Peter Lang AG.

SCHARPF F. (2015), “After the Crash: A perspective on multilevel European democracy”, European Law Journal, 21, 3, pp. 384-405.

SOEDERBAUM F., BAERT F. \& SCARAMAGLI T. (eds.) (2016), Intersecting Interregionalism, Dordrecht, The Netherlands, Springer.

STREECK W. (2013), Buying Time: The delayed crisis of democratic capitalism, London \& New York, Verso.

TELÒ M. (ed.) (2001/2007/2014), European Union and New Regionalism, Burlington, VT, Ashgate. TELÒ M. (2009), International Relations: A European perspective, Abington, UK, Ashgate.

TELÒ M. (ed.) (2014), Globalization, Multilateralism, Europe: Towards a better global governance, Burlington, VT, Ashgate.

TELÒ M. (2016), Regionalism in Hard Times: Competitive and post-liberal trends in Europe, Asia, Africa, and the Americas, Abingdon, UK, Routledge. 
TELÒ M. (2017), “The Emerging Conflict between Democratic Legitimacy and the EU's Common Commercial Policy Risks for the EU as a Civilian Power and for the Multilateral order", Annals of the Fondazione Einaudi, January 12, Turin.

TELÒ M. (2018), “L'EU face à la multiplication des interconnexions commerciales interrégionales et à leurs implications politiques", in DE BLOCK C. (ed.), Géneration TAFTA: Les nouveaux partenariats de la mondialisation, Rennes, France, Presses Universitaires de Rennes, pp. 37-55.

TELÒ M., PONJAERT F. (eds.) (2013), The EU's Foreign Policy. What kind of power and diplomatic action?, Burlington, VT, Ashgate.

TERCOVICH G. (2019), The EU Interregional Influence in Comparison: The case of institutionalization of ASEAN disaster management, $\mathrm{PhD}$ dissertation, GEM program, Université Libre de Bruxelles \& Warwick University.

YAN X. (2019), Leadership and the Rise of Great Powers, Princeton, NJ, Princeton University Press.

YUSUF A. (2014), Pan-Africanism and International Law, The Hague, Academy.

ZHAO T. (2016), A Possible World of All Under Heaven System: The world order in the past and for the future, Beijing, CITIC Press Group.

\section{ABSTRACTS}

This article draws the attention firstly on the diffusion of macro-regional organizations in each continent as well as on the inter-regional relations. Secondly it places this intermediary levels of governance - between states and global organizations - in the context of the big challenge of the interpretation of the current global order change after 1991.

On the basis of a sophisticated conceptualization of both regionalism and inter-regionalism the articles addresses the impact of the multipolar power structure of the world, on regional cooperation. Two alternative scenarios are forecasted as outcome of this comparative research: either an instrumental and authoritarian downgrading of regional cooperation as influence spheres of great powers or the gradual emergence of a new multilateralism, post-hegemonic multilayered, more legitimate and more efficient.

Cet article attire en premier lieu l'attention sur la diffusion des organisations macro-régionales dans chaque continent ainsi que sur les relations entre les régions. Deuxièmement il situe ce phénomène intermédiaire entre les Etats et les organisations globales au sein du grand thème du changement de l'ordre mondial après 1991.

Sur la base d'un côté d'une conceptualisation du régionalisme et de l'autre de l'interrégionalisme, il aborde la question de savoir quelles conséquences la structure multipolaire de l'ordre mondial produit sur les régions. Deux scenarii découlent de cette l'analyse comparée : une dégradation instrumentale autoritaire du régionalisme dans les sphères d'influence des grandes puissances ou l'émergence graduelle d'un multilatéralisme nouveau: post-hégémonique, à plusieurs niveaux, plus légitime et efficace.

\section{INDEX}

Mots-clés: régionalisme, interrégionalisme, multilatéralisme, multipolarité, ordre mondial Keywords: regionalism, interregionalism, multipolarity, multilateralism, global order 
AUTHOR

MARIO TELÒ

Institut Etudes Européennes de l'Université Libre de Bruxelles, mario.telo@ulb.ac.be 